https://helda.helsinki.fi

\title{
Cadmium in Forest Mushrooms After Application of Wood Ash
}

\section{Lodenius, M.}

Springer-Verlag New York Inc.

2002

Lodenius, M., Soultanpour-Gargari, A. and Tulisalo, E. 2002. Cadmium in Forest Mushrooms pÿAfter Application of Wood Ash. Bulletin Environmental Contamination and Toxicology (2002) 68:211 216.

http://hdl.handle.net/1975/181

Downloaded from Helda, University of Helsinki institutional repository.

This is an electronic reprint of the original article.

This reprint may differ from the original in pagination and typographic detail.

Please cite the original version. 


\title{
Cadmium in Forest Mushrooms After Application of Wood Ash
}

\author{
M. Lodenius, A. Soltanpour-Gargari, E. Tulisalo
}

Department of Limnology and Environmental Protection, Post Office Box 62, FIN-00014, University of Helsinki, Finland

Received: 15 July 2001/Accepted: 25 September 2001

The Finnish industry produces large amounts of wood ash which is partly recycled by using it as a forest fertilizer. One disadvantage is the highly variable, although generally high concentration of cadmium in wood ash. The concentrations in Finnish and Swedish wood ashes have been reported to vary from 3 to $70 \mu \mathrm{g} \mathrm{g}^{-1}$ (Korpilahti et al. 1998, Lundborg 1998, Nilsson \& Ericsson 1998).

The uptake of elements in mushrooms shows a large interspecific variation. The highest concentrations are usually found in lawn decomposing species while the levels often are considerably lower in wood decomposing and mycorrhizal species. However, also within the group of mycorrhizal fungi the variation is large (Kuusi et al. 1981, Lodenius et al. 1981). In forests the mycorrhizal species dominate the fungal community. Cadmium is rather phytotoxic and has a growth inhibition effect on basidiomycetic fungi (Baldrian \& Gabriel 1997) but the toxic effects are not known in detail. Cadmium and other heavy metals may influence the mycorrhizal colonization of tree roots (e.g. Jentschke et al. 1999, Ohtonen \& Tuohenmaa 1999) and indirectly also the uptake of metals into the roots and the growth of the tree. The aim of this investigation was to study the effect of wood ash application on the cadmium concentrations of some macrofungi in a south Finnish forest area.

\section{MATERIALS AND METHODS}

Fruiting bodies were collected in late summer - autumn 1999 and 2000 from three study plots treated with ash and two nearby control plots situated in Evo, southern Finland $\left(61^{\circ} 14^{\prime} \mathrm{N}, 25^{\circ} 12^{\prime} \mathrm{E}\right.$; Fig. 1). The soils are moraine and peat and the forests contain stands of Scots pine (Pinus sylvestris) and Norway spruce (Picea abies) with some deciduous trees (Betula spp., Alnus incana). Clear cutting has been carried out on some parts of the study areas. Approximately $4.8 \mathrm{t}(\mathrm{dw}) /$ ha of wood ash was applied in February 1998. This ash contained 9.2 $\mu \mathrm{g}$ of cadmium per $\mathrm{g}$ (dw) giving an average cadmium load of $44 \mathrm{~g} / \mathrm{ha}$. The ash was applied manually which gave a rather uneven distribution. In the summer 1999 the ash application had caused an average increase in surface $(0-7 \mathrm{~cm})$ soil $\mathrm{pH}_{(\mathrm{H} 2 \mathrm{O})}$ from 4.4 to 5.8 in mineral soils and from 4.5 to 6.1 in peat soils (Pihlström et al. 1999). 


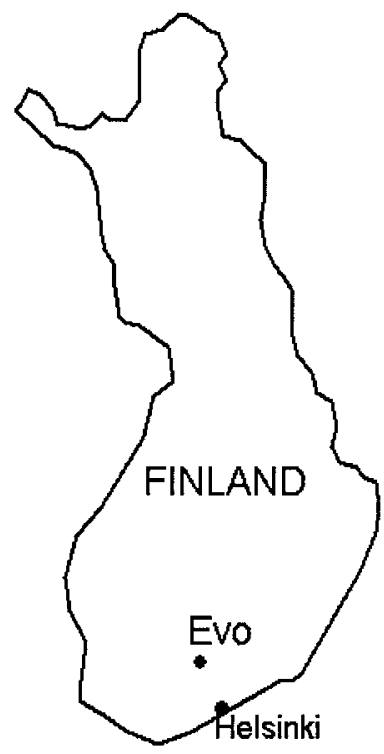

Figure 1. Location of the study area.

The mushroom samples collected represented mainly mycorrhizal species. Both stems and caps were included and they were analysed in duplicate. Samples weighing approximately $0.2 \mathrm{~g}(\mathrm{dw})$ were cleaned and dried at $105^{\circ} \mathrm{C}$, homogenized, heated in glass tubes in $5 \mathrm{ml}$ of $\mathrm{HNO}_{3}$ (BDH Aristar) for $2 \mathrm{~h}$ at $50^{\circ} \mathrm{C}$, and after that for four hours at $105^{\circ} \mathrm{C}$ and four hours at $180^{\circ} \mathrm{C}$. The sample solutions were filtered and diluted with distilled water to $25 \mathrm{ml}$ and thereafter analysed for their Cd concentrations by a graphite furnace AAS (Varian SpectrAA 400 equipped with GTA-96). The accuracy of our method was tested using a standard reference material (Table 1).

The differences between results from treated and control areas were studied by using One Way AOV from log values (Statistix software).

Table 1. Cadmium concentrations (mean \pm S.D.) of a standard reference material: Bovine liver (NIST SRM 1577a) and our detection limit.

Certified

Obtained $(n=6)$

Our detection limit
$0.44 \pm 0.06 \mu \mathrm{g} / \mathrm{g}$

$0.45 \pm 0.01 \mu \mathrm{g} / \mathrm{g}$

$0.01 \mu \mathrm{g} / \mathrm{g}$ 


\section{RESULTS AND DISCUSSION}

The cadmium concentrations summarized in Table 2 indicate higher means in treated areas for nine species out of ten. This difference is statistically significant for one species only. Calculating relative differences separately for all species we found an overall relative increase of $56 \%$.

The cadmium concentrations in the mycorrhizal Lactarius species (L. trivialis and L. rufus) ranged $0.11-3.5 \mu \mathrm{g} / \mathrm{g}(\mathrm{dw})$. This may be compared to the results of Kuusi et al. (1981) who found in mean 1.0 from Lactarius species ( $L$. necator excluded) in the Helsinki area while the mean for rural areas was $0.8 \mu \mathrm{g} / \mathrm{g}$. Moilanen and Issakainen (2000) studied L. rufus from ash treated areas 13-27 years after ash application and found in mean $1.5 \mu \mathrm{g} / \mathrm{g}(\mathrm{N}=16)$ while the mean for control areas was $1.9 \mu \mathrm{g} / \mathrm{g}(\mathrm{N}=16)$. In L. trivialis the mean concentration $52-53$ years after ash application was $0.3 \mu \mathrm{g} / \mathrm{g}(\mathrm{N}=6)$ while it was $0.5 \mu \mathrm{g} / \mathrm{g}(\mathrm{N}$ $=6$ ) in control areas.

Table 2. Cadmium concentrations $(\mu \mathrm{g} / \mathrm{g} \mathrm{dw}$ ) of fungi from treated and control sites in Evo. The risk level "p" refers to the difference between the means for treated and control areas (One Way AOV, calculated when $\mathrm{N}$ at least $=5$ ).

\begin{tabular}{lcccc}
\hline & & Treated & Control & $\mathrm{p}$ \\
& $\mathrm{N}$ & Mean \pm SD & Mean $\pm \mathrm{SD}$ & \\
\hline Albatrellus ovinus & $2+2$ & $0.75 \pm 0.08$ & $0.36 \pm 0.06$ & - \\
Lycoperdon perlatum & $2+2$ & $1.3 \pm 0.41$ & $0.64 \pm 0.57$ & - \\
Cantharellus sp. & $2+2$ & $0.28 \pm 0.20$ & $0.46 \pm 0.42$ & - \\
Clitocybe sp. & $10+10$ & $1.3 \pm 1.07$ & $0.75 \pm 0.47$ & 0.269 \\
Hygrophoropsis aurantiaca & $2+2$ & $0.41 \pm 0.06$ & $0.30 \pm 0.15$ & - \\
Lactarius rufus & $6+6$ & $1.2 \pm 1.1$ & $0.99 \pm 0.75$ & 0.710 \\
Lactarius trivialis & $5+5$ & $0.29 \pm 0.22$ & $0.23 \pm 0.15$ & 0.566 \\
Leccinum scabrum & $8+8$ & $2.0 \pm 1.6$ & $1.8 \pm 1.6$ & 0.630 \\
Russula emetica & $5+5$ & $3.6 \pm 3.8$ & $0.57 \pm 0.18$ & 0.042 \\
Rozites caperata & $1+1$ & 23 & 10 & - \\
Gyromitra esculenta & $1+1$ & 2.9 & 2.3 & - \\
\hline
\end{tabular}

In Russula emetica the mean concentrations were significantly higher at treated sites $(0.5-9.4 \mu \mathrm{g} / \mathrm{g})$ than at control sites $(0.28-0.63 \mu \mathrm{g} / \mathrm{g})$. Also Kuusi et al. (1981) found a much higher mean concentration for Russula spp. in the more polluted Helsinki area $(2.2$, range 0.6-7.7 $\mu \mathrm{g} / \mathrm{g}, \mathrm{N}=12)$ compared to rural areas (mean 0.4, range $<0.2-07 \mu \mathrm{g} / \mathrm{g}, \mathrm{N}=9$ ). Vetter (1994) reported a higher accumulation potential in three sections of the genus Russula (Ingratea, Heterophyllae and Xerampelinae), whereas others have a low cadmium level. Russula emetica belonging to the subsection Emeticinae obviously also belong to this group and this species seems to be a sensitive indicator of changes in environmental cadmium status. 
Also in Clitocybe species (including C. gibba, C. clavipes and undetermined Clitocybe) the mean concentration was higher in treated areas (range $0.18-1.7$ ) than in control areas (range 0.12 - 3.9) but the difference was not statistically significant. In Gyromitra esculenta, which grows in the spring the concentration was higher in the treated area (one sample only). As far as we now, cadmium concentrations have not been reported for this species.

In Leccinum scabrum there was no significant difference between treated and control areas (range for all samples $0.32-5.8 \mu \mathrm{g} / \mathrm{g}$ ). Kuusi et al. (1981) found in mean $5.3 \mu \mathrm{g} / \mathrm{g}$ (range $0.3-25, \mathrm{~N}=7$ ) from other Boletacae species than Boletus edulis in the Helsinki area while the mean concentration was $1.3 \mu \mathrm{g} / \mathrm{g}$ (range 0.4 - 4.0, $\mathrm{N}=17$ ) in rural areas. Moilanen and Issakainen (2000) analysed Suillus variegatus from 9-11 years old ash treated areas and got a mean of $1.0 \mu \mathrm{g} / \mathrm{g}$ for both treated $(\mathrm{N}=6)$ and control areas $(\mathrm{N}=6)$.

In Hygrophoropsis aurantiaca the two samples from treated areas showed a higher mean concentration than the two from control areas. In Cantharellus $(C$. cibarius and $C$. tubaeformis $)$ the concentrations were higher in control areas $(0.16$ and $0.75 \mu \mathrm{g} / \mathrm{g} \mathrm{dw})$ than at the treated sites $(0.14$ and $0.42 \mu \mathrm{g} / \mathrm{g} \mathrm{dw})$. In the Helsinki area Kuusi et al. (1981) found a concentration range of $0.4-2.0 \mu \mathrm{g} / \mathrm{g} d \mathrm{w}$ $(\mathrm{N}=5)$ while the range in rural areas was $0.2-1.2 \mu \mathrm{g} / \mathrm{g} \mathrm{dw}(\mathrm{N}=5)$ for these two Cantharellus species. Jorhem and Schröder (1995) found a mean of $0.44 \mu \mathrm{g} / \mathrm{g} \mathrm{dw}$ in a reference material of C. tubaeformis from central Sweden.

Also in Albatrellus ovinus there was an statistically insignificant difference between treated $(0.69$ and $0.80 \mu \mathrm{g} / \mathrm{g} \mathrm{dw})$ and control areas $(0.32$ and $0.40 \mu \mathrm{g} / \mathrm{g}$ $\mathrm{dw}$ ), which may be compared with the mean for rural areas by Kuusi et al. (1981) $0.8 \mu \mathrm{g} / \mathrm{g} \mathrm{dw}$ (range $0.5-1.9, \mathrm{~N}=4$ ). In this species Jorhem and Sundström (1995) found fresh weight concentrations ranging from 0.014 to $0.15(\mathrm{~N}=6)$ in central Sweden.

In the lawn decomposer species Lycoperon perlatum the concentrations were higher at treated sites $(1.0$ and $1.6 \mu \mathrm{g} / \mathrm{g} \mathrm{dw})$ than in control areas $(0.23-1.0 \mu \mathrm{g} / \mathrm{g}$ $\mathrm{dw})$. Kuusi et al. (1981) found $0.2-7.5 \mu \mathrm{g} / \mathrm{g} \mathrm{dw}(\mathrm{N}=14)$ in Gasteromycetes from the Helsinki area and $0.5 \mu \mathrm{g} / \mathrm{g} \mathrm{dw}$ in one sample from a rural site while Jorhem and Sundström (1995) reported a range of $0.05-0.24 \mu \mathrm{g} / \mathrm{g}$ (fresh weight, $\mathrm{N}=5$ ).

Rühling (1996) studied the effects of treatment with ash on species composition and metal concentrations of fungi in pine, spruce and birch forest stands in southern Sweden. Considerable differences were observed for some fungi. Within most of the experimental areas there were fewer mycorrhiza-forming species, such as Russula and Boletus while ash application seemed to enhance the occurrence of litter-decomposing species such as Clitocybe and Lycoperdon. However, he found only one species, Cortinarius paleaceus, which contained significantly higher concentrations of cadmium on the treated areas. Usually the variation in metal 
concentrations between different species within the same plot were larger than within one species after different treatments.

The cadmium levels found in Evo are similar to results from comparable areas. When comparing treated and control areas, application of wood ash seem to elevate the cadmium concentrations of macrofungi. After two years this increase is rather moderate and results from other experiments (Rühling 1996, Moilanen \& Issakainen 2000) indicate that no significant changes will occur after longer periods of time. This may partly be a result of decreasing mobility in connection with increasing $\mathrm{pH}$. However, the forest soil has been enriched with cadmium and the cadmium status should be monitored also in future.

\section{Acknowledgments.}

We gratefully acknowledge financial support from the Academy of Finland and the Ministry of the Environment (project EEMA).

\section{REFERENCES}

Baldrian P, Gabriel J (1997) Effect of heavy metals on the growth of selected wood-rotting basidiomycetes. Folia Microbiol 42:521-523

Jentschke G, Winter S, Godbold D (1999) Ectomycorrhizas and cadmium toxicity in Norway spruce seedlings. Tree Physiol 19:23-30

Jorhem L, Sundström B (1995) Levels of some trace elements in edible fungi. Z Lebensm Unters Forsch 201:311-316

Jorhem L, Schröder T (1995): Characterisation of a fungus reference material, and a guide for use. Z Lebensm Unters Forsch 201:317-321

Korpilahti A, Moilanen M, Finér L (1998) Biomass ash utilization in Finland. In: Obernberger I (ed.): Ashes and particulate emissions from biomass combustion. Formation, characterisation, evaluation, treatment. Inst Chem Engin, Techn Univ Graz Vol 3:43-54

Kuusi T, Laaksovirta K, Liukkonen-Lilja H, Lodenius M, Piepponen S (1981) Lead, cadmium and mercury contents of fungi in the Helsinki area and in unpolluted control areas. Z Lebensm Unters Forsch 173:261-267

Lodenius M, Kuusi T, Laaksovirta K, Liukkonen-Lilja H, Piepponen S (1981) Lead, cadmium and mercury content of fungi in Mikkeli, SE Finland. Ann Bot Fennici 18:183-186

Lundborg A (1998) Ecological and economical evaluation of biomass ash utilization - the Swedish approach. In: Obernberger I (ed.): Ashes and particulate emissions from biomass combustion. Formation, characterisation, evaluation, treatment. Inst Chem Engin, Techn Univ Graz Vol 3:29-41 
Moilanen M, Issakainen J (2000) Tuhkalannoituksen metsävaikutukset [In Finnish; Effects of ash fertilization on forests]. Metsätehon raportti 93. Helsinki. 38 p

Nilsson K, Ericsson SO (1998) Ashes from CFB combustion and gasification plants using woody biofuels - results from test runs. In: Obernberger I (ed.): Ashes and particulate emissions from biomass combustion. Formation, characterisation, evaluation, treatment. Inst Chem Engin, Techn Univ Graz Vol 3:89-103

Ohtonen R, Tuohenmaa H (1999) Tuhkalannoituksen vaikutus männyn ektomykorritsasymbioosiin kangasmaalla [In Finnish; Effects of ash fertilization on ectomycorrhizal symbiosis of pine]. Metsätehon raportti 84 . Helsinki. $18 \mathrm{p}$

Pihlström M, Rummukainen P, Mäkinen A (1999) Tuhkalannoitusprojektin kasvillisuus- ja maaperätutkimukset Evolla 1997 - 1999 [In Finnish; Vegetation and soil research of the ash fertilization project at Evo 19971999]. Final report. Metsäteho Ltd. 43 p

Rühling $\AA$ (1996) Upptag av tungmetaller i svamp och bär samt förändringar i florans sammansättning efter tillförsel av aska till skogsmark. NUTEK Rapport 1996:49, Stockholm, $46 \mathrm{p}$

Vetter J (1994) Data on arsenic and cadmium contents of some common mushrooms. Toxicon 32:11-15. 